\section{AKIBAT HUKUM PAJAK GANDA DALAM PERSPEKTIF HUKUM INTERNASIONAL ${ }^{1}$ Oleh : Putri Anugerah Unsulangi ${ }^{2}$}

\begin{abstract}
ABSTRAK
Tujuan dilakukannya penelitian ini adalah untuk mengetahui bagaimana akibat Hukum pajak ganda dalam perspektif hukum Internasional dan bagaimana cara penghindaran terjadinya pajak ganda. Dengan menggunakan metode penelitian yuridis normatif, disimpulkan: 1 . Akibat hukum pajak ganda dalam perspektif hukum internasional adalah mengakibatkan tambahan beban bagi wajib pajak akibat adanya pengenaan pajak ganda. Terjadinya konflik hukum pajak sangat tergantung pada azas-azas pengenaan pajak yang dianut oleh masing-masing Negara yang bersangkutan. Bila dua Negara menganut azas yang berlainan hal itu dapat menimbulkan pajak ganda. Oleh karena itu, akibat yang ditimbulkan karena adanya pengenaan pajak berganda adalah : Memberikan tambahan beban ekonomi terhadap pengusaha; Dengan adanya perluasan usaha ke mancanegara akan mengundang risiko terkena pemajakan berganda; Memicu ekonomi global dengan biaya tinggi dan menghambat mobilitas global sumber daya ekonomis. 2. Cara penghindaran pajak berganda dapat dilakukan dengan berbagai upaya, cara serta metode. adapun cara dan metode yang dapat digunakan untuk menghindari terjadinya pajak berganda yaitu : cara unilateral, cara bilateral, cara multilateral, metode pembebasan atau pengecualian, metode pengurangan pajak dan metode lainnya.

Kata kunci: Akibat Hukum, Pajak Ganda, Perspektif Hukum Internasional
\end{abstract}

\section{PENDAHULUAN}

\section{A. Latar Belakang}

Secara umum pemajakan dibagi dalam duadimensi yaitu pemajakan terhadap wajib pajak dalam negeri dan pemajakan terhadap wajib pajak luar negeri, terhadap penghasilan atas suatu penghasilan secara bersama oleh negara domisili dan negara sumber, ini yang

\footnotetext{
${ }^{1}$ Artikel Skripsi. Dosen Pembimbing: Godlieb N. Mamahit, $\mathrm{SH}, \mathrm{MH}$; Said Aneke R, SH, MH

2 Mahasiswa pada Fakultas Hukum Unsrat, NIM. 16071101251
}

menyebabkan timbulnya pajak berganda internasional. Pajak berganda Internasional adalah pengenaan pajak duakali atau lebih terhadap subjek atau objek yang sama oleh dua negara atau lebih mengenakan pajak atas objek yang sama dan subjek pajak yang sama ${ }^{3}$. Meskipun telah ada hukum pajak internasional, dengan sistem perpajakan yang berbeda-beda antar Negara, dapat menimbulkan terjadinya pengenaan pajak berganda, yang dapat menimbulkan terjadinya penyelundupan pajak atau penghindaran pajak dengan melakukan kegiatan illegal agar mendapatkan beban pajak yang minim dengan memanfaatkan berbagai celah yang ada dan terbuka untuk tidak atau mengelak membayar kewajiban pajak di Negara sumber penghasilan atau di Negara domisili ${ }^{4}$.

Terlepas dari kenyataan bahwa suatu hubungan ekonomi Internasional semakin maju dan berkembang, maka perlu adanya suatu aturan yang diatur dalam suatu himpunan peraturan untuk mengatur kepentingan dari semua negara- negara seperti perdamaian, keamanan, keadilan, kemakmuran, dan sebagainya serta aspek-aspek yang dapat menimbulkan permasalahan di kemudian hari. Dengan adanya himpunan peraturan tersebut, menjadikan orang pribadi yang bertempat tinggal dan badan yang berkedudukan disuatu negara bersedia melakukan perdagangan, menjalankan usaha atau bahkan melakukan investasi termasuk di Indonesia dan sebaliknya orang pribadi atau badan Indonesia yang melakukan aktivitas yang sama kemancanegara.

Seiring bertambah luasnya dan majunya hubungan ekonomi internasional, makin terasa perlunya diadakan rekonsiliasi yurisdiksi pajak dari negara-negara yang bersangkutan. Dengan adanya rekonsiliasi ini, hak pemajakan masingmasing negara diatur secara tegas, sehingga kemungkinan terjadinya pengenaan pajak berganda semakin kecil. Rekonsiliasi dari dua yurisdiksi yang berbeda ini biasanya disebut persetujuan penghindaran pajak berganda (tax treaty atau tax convention $)^{5}$. Persetujuan

\footnotetext{
3 Safri Nurmantu, Pengantar Perpajakan. (Jakarta2005): Yayasan Obor, hal 165.

${ }^{4}$ Sony Devano dan Siti Kurnia R, Perpajakan, Konsep, Teori dan Isu, Kencana Prenada Media Group, (Jakarta: 2006), Hal 205.

${ }^{5}$ Rachmanto Surahmat, 2000, Persetujuan Penghindaran Pajak Berganda, Jakarta: Gramedia Pustaka Utama, hal 2.
} 
penghindaran pajak berganda adalah dua negara yang mengadakan kesepakatan tentang saling membagi hak pemajakan atas penghasilan penduduknya yang melakukan usaha di negara lain 6 .

Kebijakan perpajakan antar negara berbeda satu sama lainnya. hal ini disebabkan oleh karena adanya perbedaan kepentingan dari masing-masing negara. selain itu masingmasing negara mempunyai kondisi yang berbeda baik sosial, politik dan ekonomi serta budaya. kondisi yang berbeda-beda tersebut menyebabkan kebijakan dibidang perpajakan pun menjadi berbeda.

Berdasarkan uraian diatas penulis tertarik untuk mengambil judul : "AKIBAT HUKUM PAJAK GANDA DALAM PERSPEKTIF HUKUM INTERNASIONAL"

\section{B. Rumusan Masalah}

1. Bagaimana akibat Hukum pajak ganda dalam perspektif hukum Internasional ?

2. Bagaimana cara penghindaran terjadinya pajak ganda?

\section{E. Metode Penelitian}

Penelitian hukum normatif sering juga disebut penelitian hukum doktrinal atau penelitian kepustakaan karena penelitian ini hanya meneliti dan mengkaji bahan-bahan hukum tertulis dan penelitian ini lebih banyak dilakukan di perpustakaan.

\section{PEMBAHASAN}

\section{A. Akibat Hukum Pajak Ganda Dalam Perspektif Hukum Internasional}

Kegiatan-kegiatan usaha yang bersifat internasional, yang melewati batas-batas yurisdiksi perpajakan suatu negara, selain di satu sisi mengandung risiko akan menimbulkan terjadinya pajak ganda (international double taxation), di sisi lain secara potensial membuka kemungkinan-kemungkinan terjadinya penghindaran dan penyelundupan pajak internasional ${ }^{7}$. Pengenaan pajak ganda akan menyebabkan bertambahnya beban pajak yang harus dipikul oleh wajib pajak. Hal ini bukan saja akan memberatkan wajib pajak, tetapi juga

\footnotetext{
${ }^{6}$ Ibid., hal 32.

7 Jaja Zakaria, 2005, Perjanjian Penghindaran Pajak Berganda, Jakarta: PT. Raja Grafindo Persada, hal 25.
}

akan menimbulkan kerugian bagi penerimaan pajak negara-negara yang bersangkutan ${ }^{8}$.

Pajak berganda sebagai akibat dari pemajakan oleh dua ketentuan pemajakan (dari dua Negara) memberikan akibat tambahan beban ekonomis terhadap pengusaha. Oleh karena itu tampak bahwa sudah merupakan kebutuhan internasional antarnegara untuk mengupayakan agar kebijakan perpajakannya bersifat netral terhadap kompetisi internasional. Netralitas tersebut dicapai dengan penyediaan keringanan atau eliminasi atas pajak berganda internasional.

Dalam praktik, pengenaan pajak oleh Negara-negara sering menimbulkan konflik hukum pajak antara Negara yang satu dengan Negara yang lain. Konflik hukum pajak itu timbul sebagai akibat adanya bentrok kepentingan untuk mengenakan pajak. Apabila terjadi konflik hukum pajak antar Negara, maka kemungkinan timbulnya pajak ganda sangat potensial. Menurut Rochmat Soemitro, terjadinya konflik hukum pajak sangat tergantung pada azas-azas pengenaan pajak yang dianut oleh masing-masing Negara yang bersangkutan. Bila dua Negara menganut azas yang berlainan hal itu dapat menimbulkan pajak ganda ${ }^{9}$.

Pajak berganda sebagai akibat dari pemajakan oleh dua ketentuan pemajakan dari dua Negara, sehingga mengakibatkan sebagai berikut :

a. Memberikan tambahan beban ekonomi terhadap pengusaha.

Pembangunan ekonomi menjadi salah satu perhatian utama pemerintah di samping masalah-masalah nasional lainnya, terutama sejak terjadinya krisis ekonomi di Indonesia. Perkembangan ekonomi suatu negara dapat tercermin dalam indikator pasar modal negara tersebut. Pemerintah telah melakukan berbagai upaya dalam rangka mendorong masuknya modal asing maupun domestik ke dalam sektorsektor yang produktif untuk membuka lapangan kerja dan meningkatkan pertumbuhan ekonomi.

Lingkungan ekonomi adalah kondisi ekonomi di negara tempat organisasi internasional beroperasi. Kondisi ekonomi

\footnotetext{
8 Ibid., hal 10

${ }^{9}$ Ibid., hal 6-7.
} 
memiliki dampak yang kuat terhadap kinerja dari setiap bisnis karena dapat mempengaruhi pendapatan atau beban dari bisnis tersebut.

Sekarang, bisnis dan investasi telah mempersubur tumbuh dan berkembangnya perusahaan multinasional. Bagi negara tujuan investasi terutama bagi negara berkembang seperti Indonesia, investasi yang dilakukan perusahaan multinasional dengan strategi aliansinya dapat memperluas dan memperbesar akses negara setempat terhadap pasar internasional. Tuntutan pasar, persaingan, serta perubahan disetiap aspek dalam lingkungan bisnis mendorong perusahaan untuk membangun keunggulan agar bisa bersaing, mendapatkan laba, serta bertumbuh secara terus menerus ${ }^{10}$.

Dalam meningkatkan daya saing dan peningkatan efisiensi tersebut, suatu perusahaan yang berada dalam satu group, apakah karena kepemilikan atau penguasaan, baik yang berskala nasional, regional maupun global pastilah melakukan suatu perencanaan atas strategi bisnis, taktis dan operasional yang telah dikaji dan dipertimbangkan secara seksama ${ }^{11}$.

Menurut Suandy salah satu hal yang mempengaruhi keputusan bisnis dari suatu perusahaan adalah pajak, baik mempengaruhi secara langsung maupun tidak langsung. Suatu keputusan bisnis yang baik jika berhubungan dengan pajak bisa menjadi keputusan bisnis yang kurang baik, begitu juga sebaliknya. Dari segi ekonomi, pajak merupakan pemindahan sumber daya dari sektor privat (perusahaan) ke sektor publik yang mempengaruhi daya beli (purchasing order) atau kemampuan belanja (spending power) dari suatu perusahaan ${ }^{12}$.

Maka dari itu sebagai wajib pajak yang rasional tentu akan selalu berusaha untuk meminimalkan beban, termasuk beban pajak. Dalam menekan beban pajak, suatu perusahaan menggunakan skema-skema transaksi keuangan yang ada di dalam dunia bisnis, apalagi jika terjadi kekosongan peraturan perundang-undangan terhadap

10 Hutabarat dan Huseini, 2012, Srategi: Pendekatan Komprehensif dan Terintegrasi, Jakarta: UI-Press, hal 264.

11 Gunadi, Op.Cit, hal 222.

12 Suandy, 2011, Hukum Pajak, edisi 5, Jakarta: Salemba Empat, hal 1. skema-skema penghindaran pajak (tax avoidance) tersebut .

Dengan adanya pengenaan pajak berganda yang dikenakan terhadap pengusaha atas subjek, objek bahkan dalam kurun waktu yang sama, yang disebabkan karena adanya perbedaan kebijakan perpajakan antar negara menyebabkan tambahan beban ekonomis bagi para pengusaha yang menjalankan bisnis maupun berinvestasi karena dikenakan pajak duakali (berganda) atas subjek maupun objek yang sama.

b. Dengan adanya perluasan usaha ke mancanegara akan mengundang risiko terkena pemajakan berganda.

Pesatnya perkembangan teknologi komunikasi, transport, informasi, dan metode berusaha mendorong globalisasi usaha perusahaan mancanegara ke Indonesia dan sebaliknya perusahaan Indonesia ke mancanegara. Sebagai pengusaha rasional, motivasi perluasan usaha ke mancanegara adalah menambah keuntungan. Tambahan ini diperoleh dari perluasan pasar, skala usaha yang semakin ekonomis karena volume produksi tambah besar, ketersediaan tenaga profesional dan manajemen yang berkualitas, bekerjanya jejaring global serta iklim usaha yang kondusif termasuk sistem perpajakan yang pro bisnis.

Perluasan usaha ke mancanegara dapat berupa ekspor barang, penunjukan agen atau perwakilan, pemberian jasa, pembukaan cabang, sampai dengan investasi langsung mancanegara berupa perolehan atau pendirian anak perusahaan di mancanegara. Selain itu secara pasif, dapat berupa pembukaan tabungan atau deposito di suatu bank mancanegara, pemberian pinjaman atau lisensi, dan pemanfaatan lainnya. Perusahaan multinasional dalam memperlebar jangkauan pasarnya melakukan perluasan kegiatan perdagangan ke mancanegara dengan membentuk cabang, anak, holdingcompany, dan/atau kantor perwakilan (head quarter) untuk memperkuat aliansi strategis guna mempertahankan dan menumbuh kembangkan pasar ekspor dan impor di berbagai negara ${ }^{13}$.

\footnotetext{
13 Gunadi, Op.Cit., hal 221.
} 
Perluasan usaha ekonomi ke yurisdiksi mancanegara menambah beberapa risiko seperti kompetisi global, risiko nilai tukar, restriksi pengiriman penghasilan atau modal oleh pemerintah negara sumber, disparitas tingkat harga, perubahan harga komoditas, modal dan harta, perolehan penghasilan dan biaya capital, risiko sosial-politis, serta terjadinya pemajakan berganda.

c. Memicu ekonomi global dengan biaya tinggi dan menghambat mobilitas global sumber daya ekonomis.

Maksudnya disini, globalisasi modal dapat terjadi baik melalui partisipasi langsung maupun tidak langsung oleh badan privat atau publik serta suatu organisasi internasional. Suatu badan usaha dapat didirikan dengan bantuan modal asing, kepemilikan saham pada suatu badan ditransfer ke mancanegara, dan pinjaman tersedia oleh kreditur bagi debitur dengan tempat tinggal yang berlainan negara. Sains dan teknologi juga melibatkan aktivitas lintas perbatasan. Hal ini Nampak pada semakin banyaknya merek dagang atau paten, proses manufaktur, pengetahuan dan pengalaman dari bidang industry, sains dan komersial menjadi tersedia secara lintas perbatasan.

Selain itu, sebagai akibat dari liberalisasi perjalanan orang antar negara, terdapat peningkatan mobilitas sumber daya manusia baik secara permanen maupun temporer. Karyawan mencari tingkat hidup yang lebih baik, kondisi kerja dan standar pengupahan, baik berdasarkan inisiatif pribadi maupun yang dimutasikan oleh perusahaan untuk mencari dan memanfaatkan potensi pasar mancanegara. Disamping alasan kekaryawanan, perjalanan orang juga ditumbuh-kembangkan oleh kegiatan pariwisata yang semakin melebar selaras dengan peningkatan kehidupan serta kemajuan komunikasi dan telekomunikasi. Perjalanan atau pergerakan orang, modal dan jasa tersebut juga diikuti dengan barang. Penyerahan barang dapat berasal dari negara berkembang, terutama bahan mentah baik berupa mineral maupun produk agraris, atau dari negara maju, terutama produk industri dan teknologi canggih.

Sehubungan dengan mobilitas internasional, modal, orang, jasa dan barang tersebut, selaras dengan fenomena perpajakan internasional, pemajakan personal berbasis global dapat menimbulkan pajak berganda, terutama memicu ekonomi global dengan biaya tinggi dan menghambat mobilitas global sumber daya ekonomis.

Dalam rangka peningkatan hubungan ekonomi dan perdagangan dengan negara lain, diperlukan suatu perangkat hukum yang berlaku khusus (lex spesialis) yang mengatur hak-hak pemajak dari masing-masing negara guna memberikan kepastian hukum dan menghindarkan pengenaan pajak berganda serta mencegah pengelakkan pajak ${ }^{14}$.

Keserempakan pemajakan berganda oleh dua negara menyebabkan terjadinya pajak berganda (tax treaty) yang dapat merupakan unsur penyebab mahalnya biaya investasi dan bisnis transnasional yang oleh karenanya merupakan penghambat mobilitas keduanya. Keringanan terhadap tax treaty yang diberikan oleh negara tempat kedudukan investor maupun tempat investasi melalui ketentuan domestik atau perjanjian pemajakan merupakan solusi yang sangat penting untuk meningkatkan iklim investasi dan memperlancar mobilitas sumber daya ${ }^{15}$.

Akibat adanya pengenaan pajak berganda oleh dua negara yang mengakibatkan tambahan beban ekonomi bagi pengusaha dan menghambat mobilitas global sumber daya ekonomis, maka di perlukan cara atau metode untuk menghindari atau mencegah terjadinya pajak berganda.

\section{B. Cara Penghindaran Terjadinya Pajak Ganda}

Pajak berganda internasional dapat dihindari dengan menggunakan saluran hukum yang telah ditentukan. Pencegahan pajak berganda internasional tidak boleh mengesampingkan asas-asas hukum pengenaan pajak, karena mengandung prinsip yang sangat mendalam dalam pengenaan pajak yang dilakukan di tiap negara ${ }^{16}$.

Dalam perpajakan internasional terdapat beberapa pendekatan untuk memperingan atau mengeliminasi P3B, yakni :

a. Cara Unilateral (sepihak)

\footnotetext{
${ }^{14}$ Djoko Muljono, Pajak Berganda?! Tidak Lagi!:Pedoman Mudah dan Praktis Memahami Tax Treaty, Yogyakarta, 2011, hal 67.

15 Ibid., hal 6.

16 Muhammad Djafar Saidi, Op.Cit., hal 288.
} 
Cara ini dilakukan dengan memasukkan ketentuan untuk menghindari pajak berganda dalam undang-undang suatu negara dengan suatu prosedur yang jelas, memiliki kekuatan hukum di dalamnya yang mengatur masyarakat atau badan internasional, yang ditetapkan sepihak oleh Negara itu sendiri. Penggunaan cara ini merupakan wujud kewibawaan dan kedaulatan suatu Negara untuk mengatur sendiri masalah pemungutan pajak dalam undang-undang ${ }^{17}$.

Keuntungan dari cara penghindaran pajak secara unilateral adalah pembuatan ketentuannya yang relatif lebih mudah, karena tidak perlu melibatkan atau tergantung kepada negara lain. Di samping itu, penerapannya pun mudah, karena sepenuhnya berdasarkan ketentuan-ketentuan undang-undang nasional. Kerugiannya, terdapat aspek-aspek pajak ganda internasional yang tidak dapat dipecahkan secara sepihak (unilateral). Misalnya pajak ganda yang timbul sebagai akibat adanya kependudukan yang rangkap (dual residence), tidak dapat dipecahkan secara sepihak, karena menyangkut kepentingan dan sistem serta hukum pajak negara lain. Disamping itu ketentuan penghindaran pajak ganda unilateral umumnya hanya mengatur penghindaran pajak untuk wajib pajak dalam negeri (resident taxpayer) tidak mengatur penghindaran pajak untuk wajib pajak luar negeri (non resident taxpayer $)^{18}$.

b. Cara Bilateral (antara dua Negara)

Cara bilateral dilakukan melalui suatu perundangan antar negara yang berkepentingan untuk menghindarkan terjadinya pajak berganda. Pencegahan pajak berganda Secara bilateral adalah pencegahan pajak berganda yang disepakati bersama antar dua negara melalui suatu perjanjian khusus yang disebut convention atau aggrement ${ }^{19}$.

Masalah-masalah pajak ganda bilateral telah timbul sejak lama, yaitu sejak abad ke 19. Misalnya, pada saat itu timbul pajak ganda atas pengenaan pajak kekayaan antara perancis dan italia. Pajak ganda dalam hal ini timbul karena pemilik kekayaan bertempat tinggal di salah satu negara, sedangkan kekayaannya terletak di

\footnotetext{
17 Chairil Anwar Pohan,Op.Cit., hal 133.

18 Jaja Zakaria, Op.Cit., hal 12.

19 Safri Nurmantu, Op.Cit., hal 172
}

negara lainnya. Kedua negara mengenakan pajak atas kekayaan yang bersangkutan ${ }^{20}$.

c. Cara Multilateral (beberapa Negara secara serempak)

Tujuan diadakannya perjanjian perpajakan multilateral, ternyata tidaklah semata-mata untuk menghindarkan terjadinya pajak ganda, tetapi mempunyai tujuan-tujuan lain. Tujuantujuan lain tersebut antara lain :

1) pengalokasian (pembagian) hak pemajakan di antara negara-negara yang mengadakan perjanjian perpajakan.

2) Mendorong perdagangan dan penanaman modal antar negara.

3) Pencegahan penyelundupan pajak ${ }^{21}$.

Suatu perjanjian perpajakan multilateral akan lebih sulit untuk dilaksanakan dibandingkan dengan suatu perjanjian perpajakan bilateral. Lain daripada itu, perjanjian perpajakan multilateral lebih kurang fleksibel dibandingkan dengan perjanjian perpajakan bilateral dalam hal-hal yang menyangkut pertambahan perubahan dan penghentian perjanjian ${ }^{22}$.

Cara multilateral dilakukan melalui suatu perundingan multilateral oleh lebih dari dua negara yang berkepentingan untuk menghindarkan terjadinya pajak berganda.

Seperti konvensi wina tahun 1961 yang memuat tentang dibebaskannya perwakilan Negara yang ditempatkan di negara lain dari pengenaan pajak. Di Indonesia hal ini berlaku bagi pejabat-pejabat perwakilan diplomatik, consular, dan pejabat-pejabat lain dari negara asing,serta orang-orang asing yang diperbantukan kepada mereka yang bekerja dan bertempat tinggal bersama-sama mereka, dengan syarat :

1) Bukan warga negara Indonesia;

2) Di Indonesia tidak melakukan pekerjaan lain atau kegiatan usaha;

3) Negara yang bersangkutan memberikan perlakuan timbal balik ( asas resiprositas).

Tiga syarat tersebut harus dipenuhi oleh perwakilan negara asing di Indonesia untuk dapat dibebaskan dari pengenaan pajak.Proses terjadinya perjanjian secara bilateral maupun multilateral tentu membutuhkan waktu yang

\footnotetext{
20 Jaja Zakaria, Op.Cit., hal 17.

21 Ibid., hal 13.

22 Ibid., hal 14-15.
} 
cukup lama karena masing-masing negara mempunyai prinsip pemajakannya masingmasing sesuai dengan kedaulatan negaranya sendiri ${ }^{23}$.

Berikut beberapa metode penghindaran pajak berganda internasional :

a. Metode pembebasan (exemption) atau pengecualian (exlusion)

Metode pembebasan atau pengecualian menghendaki suatu negara pemegang yurisdiksi pemajakan sekunder (domisili) untuk dengan rela melepaskan hak pemajakannya dan sepertinya mengakui pemajakan eksklusif di negara lain (negara sumber). Menurut gunadi metode pembebasan meliputi :

1) Pembebasan subjek (subject exemption) Umumnya diberlakukan terhadap anggota-anggota diplomatik, konsuler, dan organisasi internasional. Para duta besar, anggota-anggota diplomatik, dan konsuler, sesuai dengan hukum internasional mendapat privilege (hak istimewa) pemajakan. Mereka hanya dikenakan pajak oleh negara pengirimnya saja (sending state). Ketentuan pemberian hak istimewa tersebut diikuti oleh hampir semua negara secara universal dan dikenal dengan istilah asas resiprositas.

2) Pembebasan objek (object, income exemption)

Diberikan dengan mengeluarkan penghasilan luar negeri dari basis pemajakan WPDN negara. Exemption without progression (eksemsi tanpa progesi) maksudnya adalah bahwa penghasilan luar negeri dari WPDN betulbetul dibebaskan dari pengenaan pajak dengan mengeluarkan (mengecualikannya) dari dasar pengenaan pajak (basis pajak) sehingga tidak akan masuk dalam unsur penghitungan progesi tariff pengenaan pajak negara domisili.

3) Pembebasan pajak (tax exemption)

Dalam metode ini, pada prinsipnya penghasilan luar negeri tetap dibebaskan dari pengenaan pajak domestik, namun untuk keperluan penghitungan pajak dan penerapan tarif pajak pengaruh progesi penghasilan luar negeri terhadap pengenaan pajak atas penghasilan global dipertahankan ${ }^{24}$.

b. Metode pengurangan pajak (tax credit)

Secara garis besar metode ini terdiri atas sebagai berikut :

1) Metode pengurangan pajak penuh (full tax credit method)

Dalam metode ini, penghasilan luar negeri merupakan objek pajak dan ikut dihitung dalam menentukan besarnya penghasilan kena pajak. Seluruh pajak yang terutang atau dibayar di luar negeri atas penghasilan luar negeri dapat dikurangkan seluruhnya terhadap pajak yang terutang atas penghasilan kena pajak.

2) Metode pengurangan pajak terbatas (ordinary tax credit method) Sebagai implikasi dari pengenaan PPh atas penggabungan penghasilan yang terutang pajak atas seluruh penghasilan yang diterima atau diperoleh dari luar negeri dan dalam negeri (worldwide income), subjek pajak dalam negeri yang memperoleh penghasilan dari luar negeri (negara sumber) akan dikenakan pajak di negara domisili. Negara tempat sumber penghasilan di atas juga kemungkinan besar akan mengenakan pajak atas penghasilan yang bersumber dari negaranya. Dengan demikian, besar kemungkinan akan terjadi pengenaan pajak berganda dimana dua yurisdiksi perpajakan yang berbeda mengenakan pajak kepada penghasilan yang sama yang diperoleh subjek pajak yang sama.

Untuk menghindari pengenaan pajak berganda ini, undang-undang pajak domestik secara unilateral memberikan solusi bahwa atas pajak yang terutang atau dibayar di luar negeri dapat dikreditkan oleh wajib pajak dalam negeri. Namun demikian, besarnya pajak yang bisa dikreditkan dibatasi tidak boleh melebihi perhitungan pajak terutang berdasarkan undang-undang pajak domestik. Metode kredit pajak

\footnotetext{
${ }^{23}$ Chairil Anwar Pohan,Op.Cit., hal 134.
}

\footnotetext{
24/bid., hal 135.
} 
yang demikian, yakni metode pembatasan tiap negara, dikenal dengan metode pengkreditan terbatas (ordinary credit method).

Namun sering kali pajak berganda internasional tidak bisa dieliminasi sepenuhnya, misalnya metode kredit pajak luar negeri di Indonesia, masih menyisakan potensi pajak berganda internasional karena ada kemungkinan pajak penghasilan yang sudah dibayar atau dipotong di luar negeri tidak sepenuhnya dapat dikreditkan di Indonesia. Masalah perpajakan internasional akan semakin kompleks jika seorang wajib pajak menjadi dual resident di dua negara di mana negara yang satu menggunakan consumption based taxation, sementara negara yang lainnya menggunakan income based taxation.

3) Metode pengurangan pajak terbatas yang dihitung per negara (per country limitation ordinary tax credit method)

Metode ini mirip dengan metode pengurangan pajak terbatas. Perbedaannya terletak dalam cara menerapkan penghitungan maksimum kredit pajak luar negeri yang boleh dikurangkan. Menurut metode pengurangan pajak terbatas, dalam penghitungan kredit pajak luar negeri, seluruh penghasilan yang diperoleh di luar negeri yang diperoleh dari berbagai negara, dijumlahkan menjadi satu, begitu juga pajaknya. Sedangkan menurut metode ini, penghitungannya dilakukan per negara. Setelah diperoleh hasil penghitungan per negara, baru seluruh maksimum kredit pajak luar negeri per negara tersebut dijumlahkan.

4) Metode tax sparing credit (tax sparing credit method)

Menurut metode ini, pada saat menghitung kredit pajak luar negeri atas penghasilan luar negeri di negara domisili, pembebasan atau keringanan pajak yang diberikan negara sumber atas penghasilan negeri tersebut akan dihitung menurut tarif pajak yang normal, seolah-olah di negara sumber tidak diberikan pembebasan atau keringanan pajak. Maksud dari pemberian sparing kredit ini adalah agar pembebasan pajak atau keringanan pajak tersebut benar-benar dapat dinikmati oleh wajib pajak yang bersangkutan ${ }^{25}$.

c. Metode Lainnya

1) Deduction

Metode ini menghilangkan pajak berganda dengan mengurangkan pajak yang kenakan di luar negeri dari penghasilan yang diperoleh dari luar negeri pada saat menghitung pajak terutang di dalam negeri.

2) Tax Sharing

Metode ini menghilangkan pajak berganda dengan cara membagi jumlah pajak yang terutang antara negara di mana penduduk berada dengan negara lain di mana penduduk tersebut mendapatkan penghasilan.

3) Division of tax power

Metode ini menghilangkan pajak berganda dengan cara mengurangkan tarif pajak atas penghasilan yang diterima di negara lain.

4) Lumpsum or forfait taxation ( pemajakan dengan jumlah tetap)

Metode pemajakan atas penghasilan dari luar negeri dengan jumlah yang tetap.

5) Rate Reduction

Metode ini menghilangkan pajak berganda dengan cara mengurangkan tarif pajak atas penghasilan yang di terima dari negara lain $^{26}$.

Ada berbagai metode dan cara untuk mencegah dan mengurangi risiko terjadinya pajak berganda. Namun terlepas dari semua itu, setiap negara pasti akan menerapkan peraturan perpajakan dan mengenakan asas tertentu yang nantinya akan menguntungkan negara mereka.

\section{PENUTUP}

\section{A. Kesimpulan}

1. Akibat hukum pajak ganda dalam perspektif hukum internasional adalah mengakibatkan tambahan beban bagi wajib pajak akibat adanya pengenaan

\footnotetext{
${ }^{25}$ Jaja Zakaria, Op.Cit., hal 34-36.

${ }^{26}$ Russel Butarbutar, Op.Cit., hal 260.
} 
pajak ganda. Terjadinya konflik hukum pajak sangat tergantung pada azas-azas pengenaan pajak yang dianut oleh masing-masing Negara yang bersangkutan. Bila dua Negara menganut azas yang berlainan hal itu dapat menimbulkan pajak ganda.

Oleh karena itu, akibat yang ditimbulkan karena adanya pengenaan pajak berganda adalah :

a. Memberikan tambahan beban ekonomi terhadap pengusaha.

b. Dengan adanya perluasan usaha ke mancanegara akan mengundang risiko terkena pemajakan berganda.

c. Memicu ekonomi global dengan biaya tinggi dan menghambat mobilitas global sumber daya ekonomis.

2. Cara penghindaran pajak berganda dapat dilakukan dengan berbagai upaya, cara serta metode. adapun cara dan metode yang dapat digunakan untuk menghindari terjadinya pajak berganda yaitu : cara unilateral, cara bilateral, cara multilateral, metode pembebasan atau pengecualian, metode pengurangan pajak dan metode lainnya

\section{B. Saran}

1. Sebaiknya pemerintah mengupayakan agar kebijakan atau peraturan perpajakan di setiap negara lebih baik, sempurna dan bersifat netral sehingga tidak menimbulkan terjadinya pajak berganda yang berdampak dan berakibat merugikan banyak pihak, terutama tambahan beban ekonomi bagi para pengusaha.

2. Fiskus atau pemerintah terutama petugas pajak perlu mensosialisasikan mengenai pajak khususnya pajak berganda serta metode dan cara untuk menghindari atau mencegah terjadinya pajak berganda, Agar masyarakat bisa mengetahui tentang pajak berganda serta bagaimana cara penghindarannya.

\section{DAFTAR PUSTAKA}

\section{Buku-Buku}

Arief, H., Hanafi, Pengantar Hukum Indonesia Dalam Tataran Historis Tata Hukum dan Politik Hukum Nasional, PT.Lkis

Pelangi Aksara, Yogyakarta, 2016

B Ilyas, Wirawan., dan Richard Burton, Hukum Pajak, Salemba empat, Jakarta, 2004

B Ilyas, Wirawan., dan Richard Burton, Perpajakan Indonesia, Salemba Empat , Jakarta, 2007

Brotodihardjo, Santoso, Pengantar Ilmu Hukum Pajak, Eresco, Bandung, 1995

Brotodihardjo. R. Santoso, Pengantar Hukum Pajak, Refika Aditama, Bandung, 1998

Butarbutar, Russel, Hukum Pajak Indonesia Dan Internasional, Gramata Publishing, Bekasi, 2017

Devano, S., dan Siti Kurnia R, Perpajakan, Konsep, Teori dan Isu, Kencana Prenada Media Group, Jakarta, 2006

Djamali, R. Abdoel, Pengantar Hukum Indonesia. Edisi Revisi, Rajawali Pers , Jakarta, 2014

Gunadi, Ketentuan Dasar Pajak Penghasilan, Salemba Empat, Jakarta, 2007

Hutabarat, dan Huseini, Srategi: Pendekatan Komprehensif dan Terintegrasi, UIPress, Jakarta, 2012

Hutagaol, John, Perpajakan Isu-isu Kontemporer, Graha Ilmu, Jakarta, 2007

Istanto, F. Sugeng, Hukum Internasional. Edisi Revisi, Cahaya Atma Pustaka, Yogyakarta, 2014

Kusumaatmadja, M., dan Etty, R. Agoes, Pengantar Hukum Internasional., PT.Alumni, Bandung, 2003

Mardiasmo, Perpajakan, Andi, Yogyakarta, 1997

Mardiasmo, Perpajakan. Edisi Revisi, Andi, Yogyakarta, 2003

Muljono, Djoko, Pajak Berganda?! Tidak Lagi!: Pedoman Mudah dan Praktis Memahami Tax Treaty, Yogyakarta, 2011

Nurmantu, Safri, Penganta Perpajakan, Yayasan Obor, Jakarta, 2005

Pohan, Chairil Anwar, Pedoman lengkap Pajak Internasional, Gramedia Pustaka Utama, Jakarta, 2018

Ratnawati, J., dan Retno Indah Hernawati, Dasar-Dasar Perpajakan, Deepublish, Yogyakarta, 2015

Saidi, M. Djafar, Pembaruan Hukum Pajak, Raja Grafindo Persada, Jakarta, 2007 
Soekanto, Soerjono, Pengantar Penelitian Hukum, Universitas Indonesia Press, Jakarta, 1986

Soekanto, S., dan Sri Mamudji, Penelitian Hukum Normatif Suatu Tinjauan Singkat, Rajawali Pers, Jakarta, 2010

Soemitro, Rochmat, Bahan Kuliah Hukum Pajak Internasional, Sub Konsorsium IImu Hukum, Direktorat Perguruan Tinggi Departemen Pendidikan dan Kebudayaan

Soemitro, Rochmat, Tinjauan Yuridis tentang Perjanjian Antar (dua) Negara mengenai Penghindaran Pajak Berganda Intemasional, dihimpun dan diperbanyak oleh : (katan Mahasiswa Notariat Fakultas Hukum UNPAD Bandung, 1973

Soemitro, Rohmat, Hukum Pajak Internasional Indonesia, PT. Eresco, Bandung, 1986

Soemitro, Rohmat, Hukum Pajak Internasional Indonesia Perkembangan Serta Pengaruhnya, Eresco, Bandung, 1997

Sri, Y. Pudyatmoko, Pengantar Hukum Pajak, Andi, Yogyakarta, 2009

Starke, J.G, Pengantar Hukum Internasional, PT.Sinar Grafika, Jakarta, 2010

Suandi, Erly, hukum pajak, Salemba Empat, Jakarta, 2008

Supramono, dan Theresia Woro, Perpajakan Indonesia, Mekanisme dan perhitungan, Andi, Yogyakarta, 2010

Surahmat, Rachmanto, Persetujuan Penghindaran Pajak Berganda., Gramedia Pustaka Utama, Jakarta, 2000

Tjahjono, A., dan Muhammad Fakhri Husein, Perpajakan, YKPN, Yogyakarta, 2000

Waluyo, dan Wirawan, Perpajakan Indonesia, Salemba Empat, Jakarta, 2003

Zakaria, Jaja, Perjanjian Penghindaran Pajak Berganda, PT. Raja Grafindo Persada, Jakarta, 2005

Peraturan Perundang-Undangan

Undang-Undang Dasar 1945

Undang-Undang Nomor 28 Tahun 2007

Tentang Ketentuan Umum dan Tata Cara

Perpajakan

Perjanjian Penghindaran Pajak Berganda (P3B)
Undang-Undang Nomor 36 Tahun 2008 Tentang Pajak Penghasilan 